Article

\title{
Nanocomposite Zinc Oxide-Chitosan Coatings on Polyethylene Films for Extending Storage Life of Okra (Abelmoschus esculentus)
}

\author{
Laila Al-Naamani ${ }^{1,2}$, Joydeep Dutta ${ }^{3}$ (i) and Sergey Dobretsov ${ }^{1,4, *}$ \\ 1 Department of Marine Science and Fisheries, Sultan Qaboos University, PO Box 34, Al-Khoud, 123 Muscat, \\ Oman; Lnaamani@hotmail.com \\ 2 Ministry of Municipalities and Water Resources, 112 Muscat, Oman \\ 3 Functional Materials, Applied Physics Department, SCI School, KTH Royal Institute of Technology, Kista, \\ SE-164 40 Stockholm, Sweden; joydeep@kth.se \\ 4 Center of Excellence in Marine Biotechnology, Sultan Qaboos University, PO Box 50, Al-Khoud, \\ 123 Muscat, Oman \\ * Correspondence: sergey@squ.edu.om; Tel.: +968-2441-3552
}

Received: 30 May 2018; Accepted: 26 June 2018; Published: 29 June 2018

\begin{abstract}
Efficiency of nanocomposite zinc oxide-chitosan antimicrobial polyethylene packaging films for the preservation of quality of vegetables was studied using okra Abelmoschus esculentus. Low density polyethylene films (LDPE) coated with chitosan- $\mathrm{ZnO}$ nanocomposites were used for packaging of okra samples stored at room temperature $\left(25^{\circ} \mathrm{C}\right)$. Compared to the control sample (no coating), the total bacterial concentrations in the case of chitosan and nanocomposite coatings were reduced by $53 \%$ and $63 \%$, respectively. The nanocomposite coating showed a 2 -fold reduction in total fungal concentrations in comparison to the chitosan treated samples. Results demonstrate the effectiveness of the nanocomposite coatings for the reduction of fungal and bacterial growth in the okra samples after 12 storage days. The nanocomposite coatings did not affect the quality attributes of the okra, such as $\mathrm{pH}$, total soluble solids, moisture content, and weight loss. This work demonstrates that the chitosan- $\mathrm{ZnO}$ nanocomposite coatings not only maintains the quality of the packed okra but also retards microbial and fungal growth. Thus, chitosan- $\mathrm{ZnO}$ nanocomposite coating can be used as a potential coating material for active food packaging applications.
\end{abstract}

Keywords: $\mathrm{ZnO}$ nanoparticle; nanocomposite coating; chitosan; antimicrobial; active food packaging

\section{Introduction}

Fruits and vegetables being perishable due to high water content are susceptible to rapid deterioration soon after harvest, requiring them to be properly packaged and stored if not consumed immediately [1]. High perishability of most fruits and vegetables has led investigators to seek new approaches to improve shelf-life. Okra (Abelmoschus esculentus, family Malvaceae) is a rich source of vitamin C, calcium, carotene, vitamin B1, folates and contains dietary fibre [2,3] and is a widely grown and consumed vegetable in African and Arabic countries [4]. However, it has a short postharvest life of about 10 days at temperatures from 1 to $10^{\circ} \mathrm{C}$ due to high respiration and water loss rates [5,6]. It is quite sensitive to bruising, desiccation, loss of chlorophyll, chilling injury, loss of tenderness (increased toughness), that usually leads to decaying following postharvest handling [5].

Packaging plays a critical role in food safety and quality acting as a barrier that protects the food from the outer environmental conditions, such as contamination by pathogens and spoilage organisms, chemical and physical hazards, thus slowing the process of deterioration $[7,8]$. Food packaging with antimicrobial properties has received attention due to the ability to arrest or delay microbiological 
decay of food products [9]. In antimicrobial packaging materials, antimicrobial substances are loaded in the packaging system to reduce the risk of contamination by pathogens $[10,11]$. One of the most successful approaches of antimicrobial packaging development is the coating of polymer surfaces with antimicrobial substances. As bacterial contamination occurs on the surface, the incorporation of antimicrobial agents as a coating provides high exposure area with minimal dissociation of biocides into the packaged food $[12,13]$. Recent studies have demonstrated that antimicrobial packaging improves the safety and quality of food products and helps in reducing the amount of preservatives in the food [14]. The preservative action of antimicrobial packaging is based on the release of the agents from the packaging material, which do the preservative action by direct contact with the food or by releasing to the surrounding space [14].

Natural polymers, such as chitosan, starch, clay, and pectin, have been used in food packaging due to their biodegradability, non-toxicity and biological properties [15-17]. Chitosan is non-toxic, film forming, and biodegradable biopolymer with antimicrobial properties, which make it ideal for the development of antimicrobial food packaging [17,18]. It is widely used in food production as a fining agent for clarification and de-acidification of fruit juices and for water purification [19]. Chitosan as a packaging material either alone or with other compounds was proved to improve shelf life while maintaining the quality of meat [20], fish [21] and vegetables [17]. Chitosan can form semipermeable film on fruits and vegetables, introducing host resistance to pathogens [22]. Delay in ripening and shelf life prolongation was observed in fruits and vegetables treated with chitosan [23]. Chitosan is usually blended with other polymers or antimicrobial agents, such as natural extracts and metal oxides to improve its mechanical resistance and antimicrobial properties [24,25]. For example, chitosan was blended with other active substances, such as gallic acid [26], grapefruit seed extract [27], poly-vinyl alcohol [17] and silver nanoparticles [28] to form effective antimicrobial packaging materials.

Metal oxides like titanium dioxide $\left(\mathrm{TiO}_{2}\right)$, zinc oxide $(\mathrm{ZnO})$ and magnesium oxide $(\mathrm{MgO})$, have been reported to render antibacterial activity with higher stability in comparison to organic antimicrobial agents [29,30]. In comparison to other metal oxides, $\mathrm{ZnO}$ nanoparticles are considered as safe materials for human beings [31]. Zinc is a ubiquitous trace metal and essential for a large number of metalloenzymes in living organisms [7]. Furthermore, $\mathrm{ZnO}$ is less toxic than other nanoparticles, such as silver nanoparticles, thus is widely used in the food industry as a supplement for zinc [7,32]. ZnO has been incorporated into the linings of food cans for meat, fish, corn and peas to preserve colour and prevent spoilage [32]. Interest has been arisen on using $\mathrm{ZnO}$ nanoparticles as food additives or incorporating them with packaging materials in order to provide antimicrobial properties [7,33,34]. Several studies proposed methods used to incorporate ZnO nanoparticles with low density polyethylene (LDPE), polypropylene (PP) and chitosan [32]. The application of chitosan coating in food was mostly presented as an edible or direct coating. Few reports proposed the use of chitosan films blended with different components for food packaging [17-21]. A recent study by Rahman and co-workers [20] proved the efficiency of chitosan- $\mathrm{ZnO}$ nanocomposite films formed into pouches in extending the shelf-life of raw meat. However, to the best of our knowledge, there are no reports on the use of chitosan- $\mathrm{ZnO}$ coated packaging materials and their application in food preservation.

In this study, the effect of low density polyethylene (LDPE) packaging films coated with chitosan and chitosan-ZnO nanocomposite on the shelf life and quality of okra (Abelmoschus esculentus) was investigated. The specific aims of this study were to: (1) prepare LDPE packaging coated with chitosan and chitosan-ZnO nanocomposites; (2) assess the quality of okra samples stored using active packaging through the evaluation of the microbiological, chemical and physical attributes of the vegetable.

\section{Materials and Methods}

\subsection{Sample Preparation}

Fresh okra (Abelmoschus esculentus) samples were purchased from a local supermarket (As Seeb, Muscat, Oman). Samples were transported to the marine research laboratory and then they were 
graded visually for their uniformity in size, shape and brightness of colour. Pieces with average size of $13 \mathrm{~cm} \times 2 \mathrm{~cm}$ (length $\times$ width) were selected for the experiment (Figure 1). Only vegetables free from insects, defects and visible blemishes were selected and used for the experiments (see below).

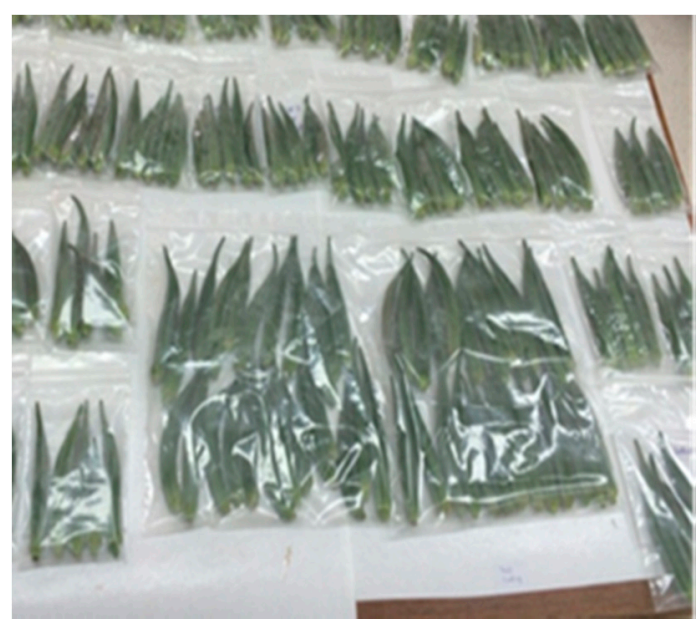

Figure 1. Photo of all the Okra samples in different polyethylene packages.

\subsection{Preparation and Characterisation of Coatings}

LDPE films coated with chitosan and chitosan- $\mathrm{ZnO}$ nanocomposites were prepared as previously described by Al-Naamani and co-workers [35]. Briefly, 2\% chitosan solution was prepared by dissolving $2 \mathrm{~g}$ of chitosan powder (Sigma Aldrich, St. Louis, MO, USA) in 0.5\% acetic acid. Then, commercial ZnO nanoparticles (35-45 nm) (Sigma Aldrich, St. Louis, MO, USA) were added to the previously prepared chitosan solution to obtain chitosan-ZnO nanocomposite. Clean LDPE films $(5 \times$ $8 \times 2 \mathrm{~cm}$ ) (Cole-Parmer Instrument Co., Cambridgeshire, UK) were treated using plasma instrument (Plasma Technology GmbH, Herrenberg-Gültstein, Germany) (pressure: 0.2 mbar, $\mathrm{O}_{2}$ : 3-4 standard cubic centimetres per minute (SCCM), power: 50\%). The atmospheric dielectric barrier discharge (DBD) plasma operated at $22 \mathrm{kHz}$ eliminating the need for impedance matching that is required for inductively coupled (ICP) plasma, radio frequency low pressure (RFP) plasma systems, making it simpler to use for a variety of applications including ashing of organic constituents, cleaning of electron microscopy sample holders and all sample surfaces, etching or structuring of surfaces as well as for the modification of surface properties (hydrophilic/hydrophobic). The system uses $230 \mathrm{~V} / 16 \mathrm{~A}$ power consumption including vacuum pump (approximately 800-1200 W) (Pfieffer, Annecy, France) with power that can be chosen from $10 \%$ to $100 \%$. Plasma treatment was used to provide a hydrophilic property to the polyethylene (PE) surface in order to result in a better attachment of chitosan to the PE surface. Oxygen or air plasma is known to removes organic contaminants by chemical reaction with highly reactive oxygen radicals and through ablation by energetic oxygen ions, promotes surface oxidation and hydroxylation (OH groups) thus increasing surface wettability. After the plasma treatment, $6 \mathrm{~mL}$ of previously prepared chitosan- $\mathrm{ZnO}$ nanocomposite solution was sprayed onto the PE surface $(10 \mathrm{~cm} \times 15 \mathrm{~cm})$ and allowed to dry at room temperature $\left(26^{\circ} \mathrm{C}\right)$. PE films coated with $2 \%$ chitosan were used for comparison, and uncoated PE was used as a control. The coated films were characterized and their antimicrobial activity was reported [35].

Surface morphology of the nano-composite coating was characterized by JEOL JSM-7200 (JEOL Ltd., Akishima, Tokyo, Japan) field emission scanning electron microscope (FESEM) working at $20 \mathrm{kV}$. The elemental composition of the coatings was determined using Energy Dispersive Spectrometry (EDS) (Oxford Instruments NanoAnalysis \& Asylum Research, UK, High Wycombe, UK). The static water contact angles of the nano-composite coatings were measured using a Theta Lite attension tensiometer (Biolin Scientific, Gothenburg, Sweden) using sessile drop technique in order to determine 
film hydrophobicity. Fourier Transform Infra-red (FTIR) spectroscopy was used to identify the chemical structure of the composite films and the possible interactions between their components. The coated and uncoated LDPE films were analysed using Attenuated Total Reflection (ATR) attachment in Frontier (FTIR) spectrometer (PerkinElmer, Waltham, MA, USA), in a spectral range from 4000 to $500 \mathrm{~cm}^{-1}$.

For determination of $\mathrm{Zn}$ ions concentration leached per $\mathrm{cm}^{2}$ of coated LDPE, pieces of the coated LDPE $(5.5 \mathrm{~cm} \times 2.5 \mathrm{~cm})$ were immersed in $20 \mathrm{~mL}$ distilled water and kept under agitation $(100 \mathrm{rpm})$ for the duration of the experiment. Water samples were collected and measured using Inductively Coupled Plasma Optical Emission Spectroscopy (ICP-OES) (Varian 710 ES, Santa Clara, CA, USA) for $\mathrm{Zn}$ determination. The analysis was done in 6 replicates.

\subsection{Experimental Design}

Selected okra samples (see sample preparation) were separated into three equal groups for the study. First group was packed in the LDPE films coated with chitosan. The second group was packed in LDPE coated with chitosan-ZnO nanocomposite. The last group was used as a control and the samples were packed in uncoated LDPE films. All okra samples were then stored for 12 days at room temperature $\left(25^{\circ} \mathrm{C}\right)$ for subsequent quality assessment (Figure 1$)$. To determine the overall quality of the samples, analysis of the chemical, physical and microbiological counts of all okra samples (see below) were carried out upon 4 and 8 and 12 days of storage.

\subsection{Microbial Analysis}

Total bacteria and total fungal count in packed okra samples was determined according to the method reported by Harrigan [36]. Briefly, $10 \mathrm{~g}$ of each samples were aseptically homogenized with $90 \mathrm{~mL}$ of peptone water for $1 \mathrm{~min}$. Ten-fold serial dilution of homogenate samples were prepared and $0.1 \mathrm{~mL}$ of each of these solutions were added onto nutrient agar (Sigma Aldrich, St. Louis, MO, USA) for bacterial analysis or potato dextrose agar (Sigma Aldrich, St. Louis, MO, USA) for fungal analysis. The inoculated agar plates were incubated at $37^{\circ} \mathrm{C}$ for $24 \mathrm{~h}$ for bacterial counts. The Petri dishes prepared for fungal counts were incubated at $30^{\circ} \mathrm{C}$ for 5 days. Samples were prepared in triplicate, and the counts between 30 and $300 \mathrm{CFU} / \mathrm{g}$ were only considered. All the results are expressed as $\log _{10} \mathrm{CFU} / \mathrm{g}$ (CFU—colony forming units).

\subsection{Chemical and Physical Properties of Okra Samples}

For the determination of $\mathrm{pH}, 5 \mathrm{~g}$ of okra sample after each treatment was homogenized thoroughly with $45 \mathrm{~mL}$ of distilled water using a blender (Panasonic Corporation, Tokyo, Japan) whereupon the $\mathrm{pH}$ was determined using a pH meter (WTW, Weilheim, Germany). Total soluble solids concentration was measured with a pocket refractometer (ATAGO, Tokyo, Japan). In order to do this, the samples were first homogenized in a blender (Panasonic Corporation, Tokyo, Japan). Then, homogenised samples were placed on the prism glass of the refractometer to take direct readings. Moisture content (wet basis) was calculated from the change in sample weight (initial weight-final weight) determined using a balance (Sartorius, Goettingen, Germany) after drying the samples in a vacuum oven at $70{ }^{\circ} \mathrm{C}$ for $24 \mathrm{~h}$. Okra weight loss was calculated by weighing okra samples before and at the last day of storage. The results, represented as means \pm standard deviation of measurements, were obtained from 10 randomly chosen samples per treatment. The difference between the initial and the final weight of the samples was considered as a total weight loss. The results are expressed as percentage loss of the initial weight.

\subsection{Statistical Analysis}

Data were subjected to the analysis of variance (ANOVA). Before the analysis, assumption of normality of the data was verified using the Shapiro-Wilk test [37]. Source of variation were the different treatments of the packaging film and storage time. Significant difference between 
different measurements were determined by Fisher Least Significant Difference (LSD) post hoc test, at a significant level $p=0.05$.

\section{Results}

\subsection{Characterisation of Coated PE Films}

The FTIR spectra of uncoated LDPE, and LDPE coated with chitosan and chitosan-ZnO nanocomposite are shown in Figure 2. The LDPE spectrum observed in this study was similar to one reported previously [38]. Methylene $\left(\mathrm{CH}_{2}\right)$ groups corresponding to the stretching modes at 2920 and $2850 \mathrm{~cm}^{-1}$ and deformations at 1464 and $719 \mathrm{~cm}^{-1}$ as shown in Figure 2 are well known in PE. After the plasma treatment, new peaks at $1720 \mathrm{~cm}^{-1}$ corresponding to $\mathrm{C}=\mathrm{O}$ stretching vibration and the region of 3200-3800 $\mathrm{cm}^{-1}$ corresponding to hydroxyl group $(-\mathrm{OH})$ vibration can be usually observed. For the chitosan coated PE films, the characteristic peaks of chitosan were observed at $3329 \mathrm{~cm}^{-1}(\mathrm{~N}-\mathrm{H}$ and $\mathrm{O}-\mathrm{H}$ stretching) and at 1649 and $1562 \mathrm{~cm}^{-1}$ (amide I and amide II) (Figure 2c). A peak at $1035 \mathrm{~cm}^{-1}$ was attributed to the stretching vibration of $\mathrm{C}-\mathrm{O}-\mathrm{C}$ [39], which suggests that chitosan is chemically bonded to polyethylene. In comparison, the spectrum of chitosan- $\mathrm{ZnO}$ nanocomposite coating has a slight shift of the bands corresponding to hydroxyl, amino, and amide groups towards lower spectral ranges (Figure $2 \mathrm{~b}$ ). This is attributed to the interaction between chitosan and $\mathrm{ZnO}$ nanoparticles.

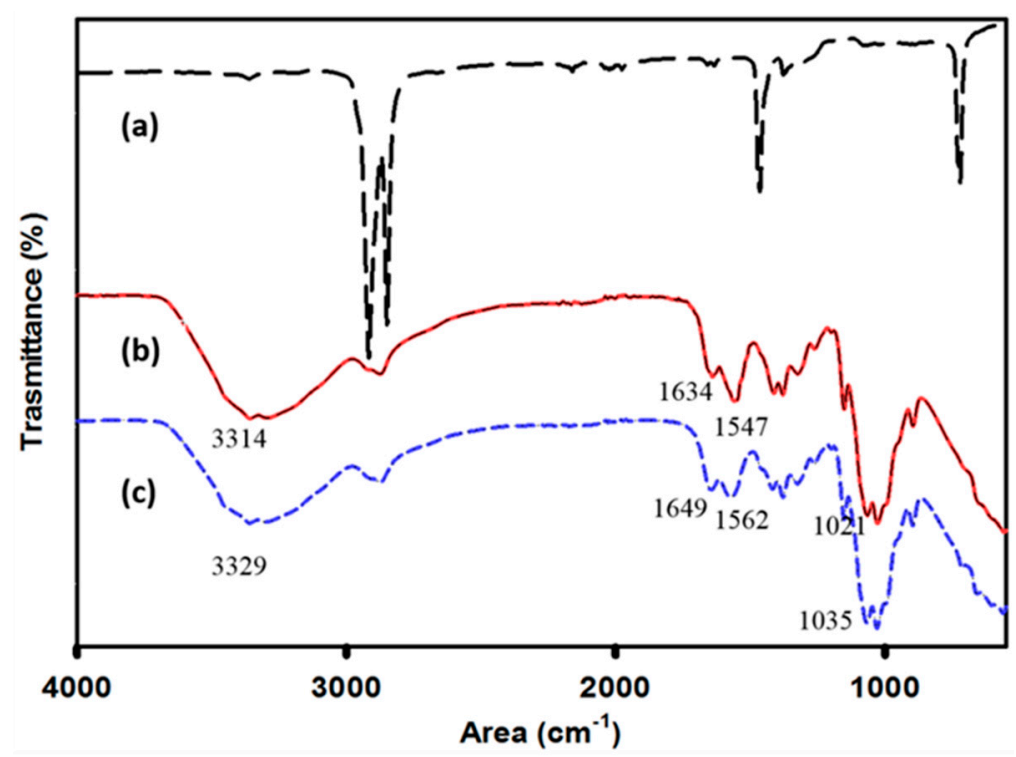

Figure 2. Fourier transform infrared FTIR spectra of low density polyethylene films (LDPE) films coated with chitosan and chitosan-ZnO nanocomposite compared to uncoated LDPE: (a) uncoated LDPE; (b) LDPE coated with chitosan-ZnO nanocomposite; (c) LDPE coated with chitosan.

Scanning Electron micrographs (SEM) confirmed the agglomeration of $\mathrm{ZnO}$ nanoparticles to about $500 \mathrm{~nm}$ in the nanocomposite coating (Figure 3a). The nanocomposite coating exhibits a hydrophobic surface with a water contact angle of $\sim 95^{\circ}$ (Figure $3 b$ ). The EDS profile proves that $\mathrm{ZnO}$ nanoparticles were successfully incorporated into the chitosan matrix as peaks of zinc were shown in the spectra (Figure 3c). ICP analysis demonstrated that total $\mathrm{Zn}^{2+}$ ion concentration that leached out from the nanocomposite coating was $0.00147 \pm 0.00008 \mathrm{mg} / \mathrm{cm}^{2}$ when it was kept under agitation for the duration of the experiment. 


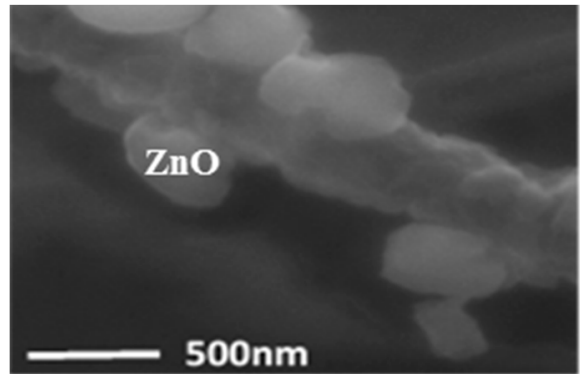

(a)

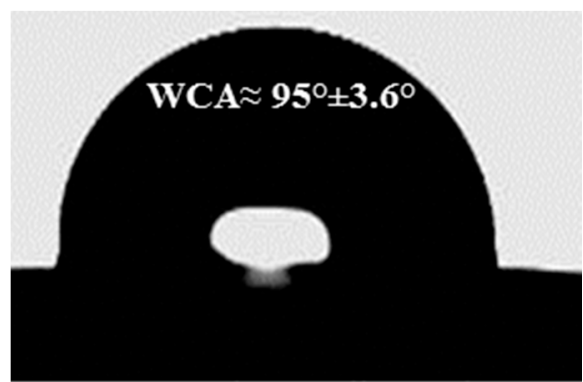

(b)

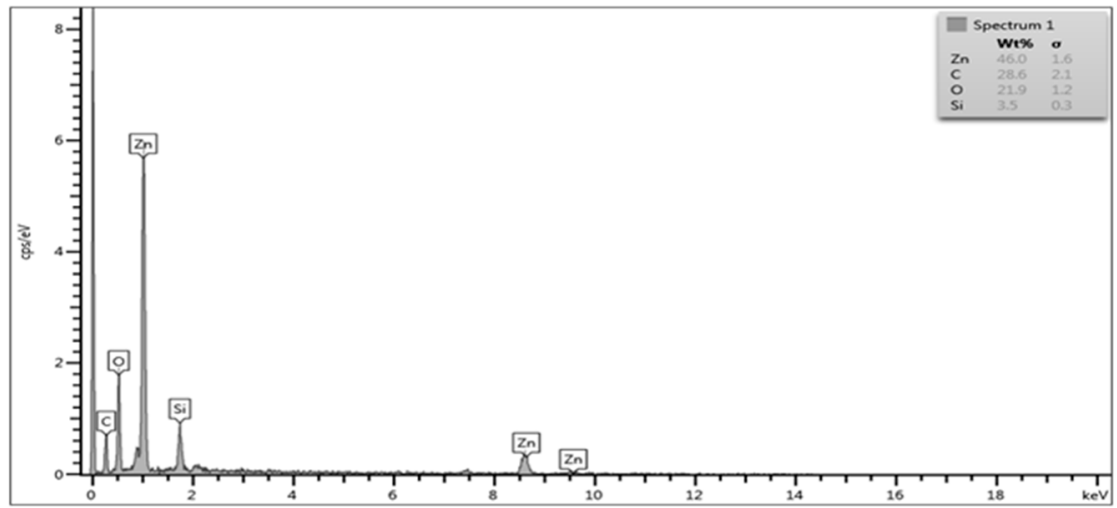

(c)

Figure 3. Characterisation of LDPE films coated with chitosan-ZnO nanocomposite. (a) SEM image of the coated LDPE $(20,000 \times)$; (b) Measurement of static contact angle of a water droplet on coated LDPE, the data are means \pm standard deviations of five replicates; (c) Energy Dispersive Spectrometry (EDS) spectrum of LDPE surface coated with Chitosan-ZnO nanocomposite. Each peak represents different elements.

\subsection{Microbial Analysis of Packed Okra}

The bacterial concentration in packed okra samples varied during the whole storage period (Figure $4 a$ ). In the first 4 days of storage, there was no significant difference (ANOVA, LSD, $p>0.05$ ) in the bacterial concentration between the control (LDPE films) or either of the treated PE films (Figure 4a). After 8 days, the bacterial CFUs increased dramatically in all the samples. Compared to the control sample, the bacterial concentrations in the case of chitosan and nanocomposite coatings were reduced by $53 \%$ and $63 \%$ respectively, though there was no significant difference (ANOVA, LSD, $p>0.05$ ) between the treatments. At the end of experiment, the concentrations of bacteria in all the samples decreased. Similar to day 8, both coatings lead to the reduction of bacterial counts in okra compared to the control (Figure 4a). There was no significant difference (ANOVA, LSD, $p>0.05$ ) between the bacterial concentrations in the treated samples.

The fungal concentrations did not differ significantly (ANOVA, LSD, $p>0.05$ ) in the first 4 days of storage in all the samples (Figure $4 \mathrm{~b}$ ). Similar to the bacterial counts, fungal concentrations in the samples stored with chitosan and nanocomposite coated films were significantly different (ANOVA, LSD, $p<0.05$ ) from the control experiments upon 8 and 12 days of storage. There was no significant difference (ANOVA, LSD, $p>0.05$ ) between the fungal concentrations in the chitosan and the nanocomposite samples after 4 and 8 days, but after 12 days fungal counts in samples stored in nanocomposite coated films decreased more than 2-folds (ANOVA, LSD, $p<0.05$ ) in comparison to the samples stored in chitosan coated LDPE films. In the control samples the fungal concentrations increased incrementally with storage time (Figure $4 \mathrm{~b}$ ). 


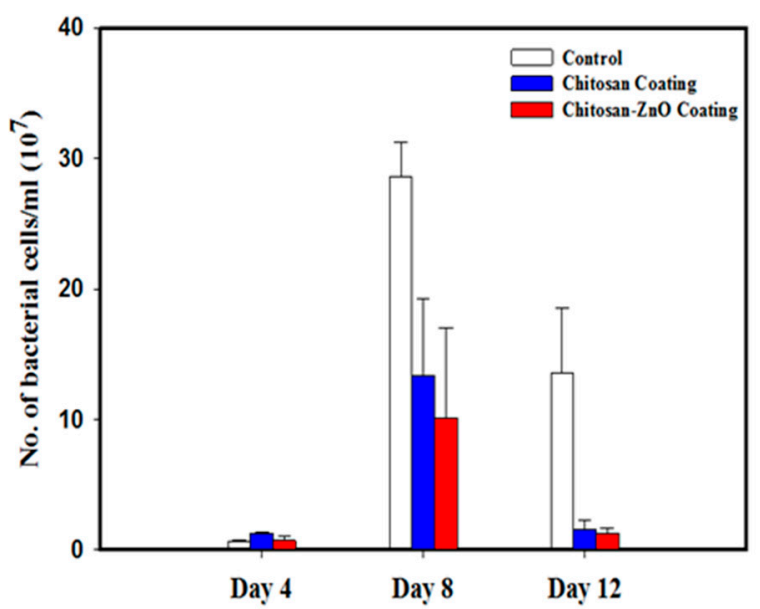

(a)

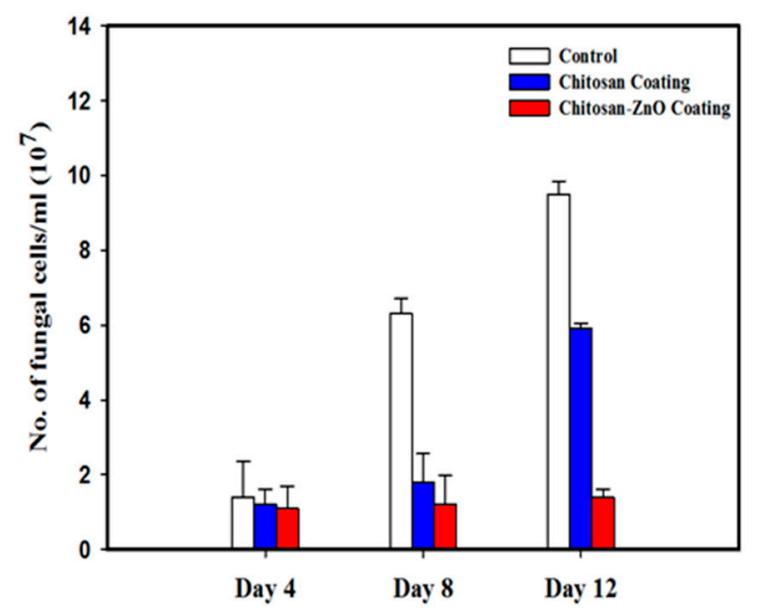

(b)

Figure 4. Number of (a) bacterial and (b) fungal cells (CFU/ml) in okra samples packed in coated and uncoated LDPE films, and incubated for 4, 8 and 12 days.

\subsection{Chemical and Physical Properties of Packed Okra}

The $\mathrm{pH}$ values of okra samples packed with uncoated LDPE, chitosan coated LDPE and LDPE coated with chitosan/ZnO nanocomposite films are presented in Table 1. There was a slight increase in acidity of all of packed okra samples during the experiments. After 12 days of storage, $\mathrm{pH}$ values decreased by $1.08 \%, 2.6 \%, 1.85 \%$ in samples packed in control LDPE films or chitosan and nanocomposite coated films, respectively with no significant difference (ANOVA, LSD, $p>0.05$ ).

Table 1. Effect of different coatings on $\mathrm{pH}$ of okra samples at each storage periods.

\begin{tabular}{ccccc}
\hline \multirow{2}{*}{ Coating Material } & \multicolumn{4}{c}{ Storage Duration (Days) } \\
\cline { 2 - 5 } & $\mathbf{0}$ & $\mathbf{4}$ & $\mathbf{8}$ & $\mathbf{1 2}$ \\
\hline Control (uncoated LDPE) & $6.47 \pm 0.06^{\mathrm{a}, \mathrm{x}}$ & $6.44 \pm 0.05^{\mathrm{a}, \mathrm{x}}$ & $6.40 \pm 0.07^{\mathrm{a}}$ & $6.40 \pm 0.01^{\mathrm{a}}$ \\
Chitosan coating & $6.47^{\mathrm{a}, \mathrm{y}} \pm 0.06^{\mathrm{a}, \mathrm{x}}$ & $6.43 \pm 0.03^{\mathrm{a}, \mathrm{x}}$ & $6.30 \pm 0.06^{\mathrm{b}, \mathrm{x}}$ & $6.30 \pm 0.07^{\mathrm{b}, \mathrm{x}}$ \\
Chitosan/ZnO coating & $6.47^{\mathrm{a}} \pm 0.06^{\mathrm{a}, \mathrm{x}}$ & $6.34 \pm 0.02^{\mathrm{y}}$ & $6.29 \pm 0.07^{\mathrm{b}, \mathrm{x}}$ & $6.35 \pm 0.03^{\mathrm{ab}, \mathrm{x}}$ \\
\hline
\end{tabular}

Note: \pm = standard deviation; Values followed by the same letters in a column $(\mathrm{a}, \mathrm{b})$ or in a row $(\mathrm{x}, \mathrm{y})$ do not differ significantly.

The amount of total soluble solids in the okra samples increased during the experiment over the period of storage (Table 2). After 4 days of storage, the amount of total soluble solids in the control samples were significantly lower (ANOVA, LSD, $p<0.05$ ) than that in the samples stored in either chitosan or nanocomposite coated LDPE films (Table 2). However, all the values increased in the eighth day with no significant difference (ANOVA, LSD, $p>0.05$ ) between them. After 12 days, the amount of total soluble solids in the sample with chitosan-ZnO nanocomposite coating was significantly lower (ANOVA, LSD, $p<0.05$ ) than the control (Table 2). 
Table 2. Effect of different coatings on total soluble solids (brix) in okra samples during different storage periods.

\begin{tabular}{ccccc}
\hline \multirow{2}{*}{ Coating Material } & \multicolumn{4}{c}{ Storage Duration (Days) } \\
\cline { 2 - 5 } & $\mathbf{0}$ & $\mathbf{4}$ & $\mathbf{8}$ & $\mathbf{1 2}$ \\
\hline Control (uncoated LDPE) & $4.7 \pm 0.8^{\mathrm{a}, \mathrm{x}}$ & $3.6 \pm 0.5^{\mathrm{b}, \mathrm{x}}$ & $5.5 \pm 1.0^{\mathrm{a}, \mathrm{x}}$ & $7.0 \pm 0.6^{\mathrm{a}}$ \\
Chitosan coating & $4.7^{\mathrm{a}, \mathrm{x}} \pm 0.8^{\mathrm{a}, \mathrm{x}}$ & $4.8 \pm 0.9^{\mathrm{a}, \mathrm{y}}$ & $4.9 \pm 0.4^{\mathrm{a}, \mathrm{x}}$ & $6.0 \pm 0.5^{\mathrm{ab}}$ \\
Chitosan/ZnO coating & $4.7 \pm 0.8^{\mathrm{a}, \mathrm{y}}$ & $5.3 \pm 0.4^{\mathrm{a}, \mathrm{x}}$ & $5.3 \pm 0.2^{\mathrm{a}, \mathrm{y}}$ & $5.5 \pm 0.1^{\mathrm{b}}$ \\
\hline
\end{tabular}

Note: $\pm=$ standard deviation; Values followed by the same letters in a column $(\mathrm{a}, \mathrm{b})$ or in a row $(\mathrm{x}, \mathrm{y})$ do not differ significantly.

Moisture content of okra stored at room temperature in the three different packaging materials is shown in Table 3. The moisture content in all samples decreased gradually during the experiment. In the first 4 days of storage, moisture content decreased insignificantly (ANOVA, LSD, $p>0.05$ ) by $2.3 \%$, $1.99 \%$ and $1.6 \%$ for the okra stored in LDPE (control) film or chitosan and nanocomposite coated films, respectively. After 8 days, the control sample lost 10-fold more moisture (ANOVA, LSD, $p<0.05$ ) than the samples packed stored in coated packages (Table 3). The control sample lost most of the moisture content within the first 8 days of storage. After 12 days okra samples lost $3.4 \%, 2.9 \%$, and $2.6 \%$ of total moisture from the samples stored in control LDPE films or chitosan and nanocomposite coated films, respectively. The difference between the treatments and the control were not significant.

Table 3. Effect of different coatings on moisture content (\%) of okra samples during different storage periods.

\begin{tabular}{ccccc}
\hline \multirow{2}{*}{ Coating Material } & \multicolumn{4}{c}{ Storage Duration (Days) } \\
\cline { 2 - 5 } & $\mathbf{0}$ & $\mathbf{4}$ & $\mathbf{8}$ & $\mathbf{1 2}$ \\
\hline Control (uncoated LDPE) & $86.3 \pm 1.1$ & $84.2 \pm 0.4$ & $83.4 \pm 1.1$ & $83.4 \pm 1.6$ \\
Chitosan coating & $86.3 \pm 1.1$ & $84.6 \pm 0.7$ & $84.1 \pm 0.9$ & $83.3 \pm 0.8$ \\
Chitosan/ZnO coating & $86.3 \pm 1.1$ & $85.2 \pm 0.9$ & $84.9 \pm 0.6$ & $84.0 \pm 1.0$ \\
\hline
\end{tabular}

Insignificant variation (ANOVA, LSD, $p>0.05$ ) in weight loss was observed among okra samples packed in the two coated films and the control after 12 days of storage. Samples exhibit values of $2.17 \% \pm 0.62,2.32 \% \pm 1.91$ and $2.03 \% \pm 1.24$ of weight loss when stored in uncoated films, chitosan or nanocomposite coated LDPE films, respectively.

\section{Discussion}

The efficiency of any antimicrobial packaging material can be evaluated by several factors. Ideal packaging should provide minimal dissociation of the incorporated antimicrobial agent into the packaged food as well as improve food safety by retarding microbial growth without changing its quality attributes [12-14]. In our experiment, chitosan was incorporated with $\mathrm{ZnO}$ nanoparticles and coated onto polyethylene films in order to develop antimicrobial packaging for food storage. This fabricated packaging was characterised and tested for its efficiency in increasing shelf life of okra samples.

The dissociation of $\mathrm{Zn}^{2+}$ ions from the packaging coating was determined throughout the experiment period. The concentration of zinc in the coating was $0.08 \mathrm{mg} / \mathrm{cm}^{2}$. After 12 days, the percentage of $\mathrm{Zn}^{2+}$ ions released was calculated to be about $1.8 \%$ of the total amount of zinc in the coating. These results showed that zinc release from the fabricated packaging material was still very low even though force was applied to intentionally increase release of $\mathrm{Zn}^{2+}$ from the coating. This confirms the stability of $\mathrm{ZnO}$ nanoparticles in the chitosan matrix. Chitosan was reported to form a network with $\mathrm{ZnO}$ nanoparticles when blended together, which could control the release of $\mathrm{Zn}^{2+}$ ions into the environment [40]. Zinc concentration value reported in our study was much lower than the 
lethal dose concentration estimated for humans on comparison with equivalent studies in animals [41]. As reported by SCF [42], the recommended upper intake level of $\mathrm{Zn}$ for human is $25 \mathrm{mg} / \mathrm{day}$.

Antimicrobial activity is a very important factor to evaluate the efficiency of the packaging to be used for food storage. The coatings used in our experiment showed good antimicrobial activity by reducing the amount of bacterial and fungal growth in packed okra samples during the twelve days of storage. In previous studies, the antimicrobial effect of direct chitosan coating of fruits and vegetables has been reported [19,43-45]. Chitosan reduced growth of grey mould [46,47], blue mould [48] and black mould [49] in grapes, strawberries and tomatoes. The growth of foodborne bacteria, such as E. coli in tomato [44] and Salmonella spp. in whole cantaloupe [45], was reported to get controlled upon the use of chitosan. Antimicrobial effect of plastic bags coated with $\mathrm{ZnO}$ nanoparticles was reported previously. Li and co-workers [50] reported 30\% reduction in E. coli count in cut apple stored in $\mathrm{ZnO}$ coated polyvinyl chloride (PVC) bags. Similarly, it was reported by Emamifar and co-workers [51] that the application of low density polyethylene (LDPE) packages blended with $\mathrm{ZnO}$ nanoparticles reduced total aerobic bacteria and total yeast and mould in fresh orange juice as well as prolonged its shelf life up to 28 days at $4{ }^{\circ} \mathrm{C}$ without any negative effects on sensory quality of the juice. In our study $\mathrm{ZnO}$ nanoparticles were mixed with chitosan and bags were coated. Since $\mathrm{ZnO}$ nanoparticles and chitosan have antimicrobial properties, we expected a synergistic effect. At the same time, the synergistic effect was observed only on reduction of fungal growth in the okra samples but no significant variation could be found in the inhibition of bacterial growth. Malini and co-workers [52] reported strong antibacterial activity of the chitosan-ZnO nanocomposite membrane with higher inhibition of the Gram negative K. planticola than Gram positive Bacillus subtilis. Liu and Kim [53] reported a similar synergistic effect of chitosan and $\mathrm{ZnO}$ nanoparticles against bacteria E. coli, P. aeruginosa, S. aureus, and B. subtilis. A study by Rahman and co-workers [20] revealed that raw beef meat packed into pouches made of chitosan films incorporated with $2 \% \mathrm{ZnO}$ nanoparticles showed complete inhibition of bacterial growth on the sixth day of storage at $4 \mathrm{C}$. The $\mathrm{ZnO}$ concentration used in this study was 20 times higher than the concentration used in our study $(0.1 \%)$, which can explain the obtained results. Several mechanisms have been proposed for the strong antimicrobial and antifungal activities of chitosan, most of them owing to the interaction of positive charges of chitosan with the negative charges of microorganisms' cells membrane [54]. It was reported that chitosan can have an effect on the permeabilization of cell membranes of some fungal species depending on their membrane fluidity [19]. Antifungal effect of chitosan can be caused by the biological mechanisms, such as inducing morphological changes, structural alterations of the fungal cells and fruit resistance induction to pathogen attacks [55]. The antimicrobial activity of $\mathrm{ZnO}$ nanoparticles is probably related to the photocatalytic generation of reactive oxygen species (ROS) on the surface of the nanoparticles [56-58]. ROS and $\mathrm{Zn}^{2+}$ ions are supposed to interact with the anionic components of microbial cell wall causing leakage of these components leading finally to cell death [59]. In the case of ZnO-nanocomposite coatings, synergistic activity was probably due to the enhancement of the positive charges of the amino group of chitosan by $\mathrm{ZnO}$ which lead to stronger interaction with negatively charged microbial cell wall [20].

Assessment of quality attributes of packed okra samples was done by measuring $\mathrm{pH}$, total soluble solids, moisture contents and weight loss of samples after each storage time. These measurements give indication of efficiency of the fabricated packaging in preserving quality characteristics of okra samples. The results showed that while acidity of okra samples slightly increased during the twelve days of storage, the $\mathrm{pH}$ values did not show any significant changes (ANOVA, LSD, $p>0.05$ ). Babarinde and Fabunmi [1] had earlier reported a reduction in $\mathrm{pH}$ from 6.7 to 6 of okra samples stored in LDPE films for 9 days. However, there were no other reports, either on okra coated with chitosan or stored in chitosan coated films. Similarly, the effect of storage of okra in chitosan-ZnO nanocomposite coated LDPE films has not been investigated. However, an increase in the $\mathrm{pH}$ of grapes honey melon was observed when directly coated with chitosan [19]. In comparison, Hernández-Muñoz and co-workers [60] observed a reduction in $\mathrm{pH}$ of strawberries coated with chitosan. These differences in 
the results about the change in acidity of fruits and vegetables could be attributed to their respective organic contents [19].

Total soluble solids indicate the proportion of dissolved solids, such as sugars, acids, amino acids, ascorbic acids and minerals in fruits and vegetables [61,62]. It is a refractometric index usually measured in Brix units which are equal to per cent of soluble solids. The increase in concentration of the total soluble solids in the sample is directly related to the increase in water loss during the storage period. The minimal effect of the chitosan coating in total soluble solids in our experiment could be due to the use of indirect coating on the package films instead of direct coating on food itself. It was reported that retention of total soluble solids in chitosan coated fruits, such as pears [63], strawberries [60] and banana [64] improved. Direct coating on fruits was reported to reduce respiration level which slows down synthesis and use of metabolites leading to slower carbohydrate hydrolysis into sugars leading to a reduction of the concentration of soluble solids $[65,66]$. However, this process depends on different other factors such as coating thickness, storage conditions and type of fruit and its ripeness stage [65].

Moisture loss in vegetables occurs due to the post-harvest physiological processes, such as respiration and transpiration [1]. The low water loss in all the samples in our experiment could be arise due to the good barrier properties of LDPE to water vapour loss and the ability to reduce respiration rate of vegetables [67-69]. It was reported previously that initial moisture content of okra is $88 \%$ and it dropped to $85 \%$ after 9 days storage in LDPE [1]. This rate is higher than moisture reduction rate observed in our experiment, which could be attributed to differences in the barrier properties of LDPE films used.

Packaging films is known to lead to the establishment of high relative humidity inside the package due to the reduction in water diffusion to the atmosphere. Thus, transpiration rate is reduced which in turn decrease weight loss in okra [70]. Babarinde and Fabunmi [1] reported 5.8\% weight loss in okra after 9 days storage in LDPE when it was stored at $28^{\circ} \mathrm{C}$. The lower loss in moisture (3.9\%) was observed when the samples were stored at lower temperatures $\left(15^{\circ} \mathrm{C}\right)$. Difference between this and our results probably due to differences in okra species and packaging films used in our study. Since there were no reports in okra packed LDPE coated with chitosan or chitosan/ZnO nanocomposite, it was not possible to compare the obtained results directly.

From all the results obtained in this work on properties of packed okra upon prolonged storage, it can be observed that the coatings on LDPE package did not influence the chemical and physical properties of okra, such as $\mathrm{pH}$, total soluble solids and moisture content. As mentioned earlier, this could be attributed to the use of indirect coating of chitosan on the plastic film. Direct coating of chitosan on fruits and vegetable are reported to affect the physical and chemical properties of coated grapes, apple, pear, tomato, sweet pepper amongst others [49,71-74]. Chitosan was reported to reduce oxygen and elevating carbon dioxide levels in coated fruits by providing a semipermeable film around them. This can modify internal atmosphere decreasing the respiration level and metabolic activities of fruits and results in ripening delays $[23,75,76]$. Manipulation of respiration levels can influence properties such as total soluble solids, moisture, weight loss and $\mathrm{pH}$ of fruits and vegetables [23]. For example, because of chitosan semipermeable barrier and its reduction of respiration rate, reduced $\mathrm{pH}$ and weight loss of coated apples [74] and reduced weight loss of pears $[63,73]$ were reported.

\section{Conclusions}

This study showed an improvement in the performance of coated LDPE films with chitosan and with chitosan/ZnO nanocomposites for the preservation of quality of okra samples by maintaining moisture content, total soluble solid and $\mathrm{pH}$ as well as preventing bacterial and fungal growth in the stored okra samples. Okra pods harvested with minimum handling were reported to have minimum rotting (3.0\%) and good appearance for the first 5 days that could be extended upon cold storage for less than 2 weeks [77]. The obtained results proved the effectiveness of the nanocomposite coating on the reduction of fungal growth in the okra samples for up to 12 storage days. Significant reduction 
in bacterial growth was observed in the samples stored in treated polyethylene films compared to the control, and the nanocomposite coating performed better for the prevention of fungal growth than chitosan alone. It can be concluded that LDPE coating with chitosan- $\mathrm{ZnO}$ nanocomposite is a promising technique in which antimicrobial property is added to the films which could influence its possible applications as active food packaging to prolong shelf-life of packed food.

Author Contributions: Laila Al-Naamani performed experiments, data analysis and was responsible for writing and revising the manuscript. Sergey Dobretsov and Joydeep Dutta were responsible for designing experiments, data analysis, reviewing, revising and editing of the manuscript.

Funding: This research was funded by the Research Council of Oman (TRC, RC/AGR/FISH/16/01) and partially by the Sultan Qaboos University-South Africa grant (CL/SQU-SA/18/01).

Acknowledgments: The authors would like to thank Soad for her help in samples preparation and analysis.

Conflicts of Interest: The authors declare no conflict of interest.

\section{References}

1. Babarinde, G.O.; Fabunmi, O.A. Effects of packaging materials and storage temperature on quality of fresh Okra (Abelmoschus esculentus) fruit. Agric. Trop. Subtrop. 2009, 42, 151-156.

2. Hosain, M.M.; Jannat, R.; Islam, M.M.; Sarker, M.K.U. Processing and Preservation of Okra Pickle. Prog. Agric. 2010, 21, 215-222. [CrossRef]

3. Petropoulos, S.; Fernandes, Â.; Barros, L.; Ferreira, I.C. Chemical composition, nutritional value and antioxidant properties of Mediterranean okra genotypes in relation to harvest stage. Food Chem. 2018, 242, 466-474. [CrossRef] [PubMed]

4. Akhtar, S.; Khan, A.J.; Singh, A.S.; Briddon, R.W. Identification of a disease complex involving a novel monopartite begomovirus with beta-and alphasatellites associated with okra leaf curl disease in Oman. Arch. Virol. 2014, 159, 1199-1205. [CrossRef] [PubMed]

5. Locascio, S.J. Comparison of cooling and packaging methods to extend the postharvest life of okra. Proc. Ha. State Hort. Soc. 1996, 109, 285-288.

6. Huang, S.; Li, T.; Jiang, G.; Xie, W.; Chang, S.; Jiang, Y.; Duan, X. 1-Methylcyclopropene reduces chilling injury of harvested okra (Hibiscus esculentus L.) pods. Sci. Hortic. 2012, 141, 42-46. [CrossRef]

7. Abad, M.A. Development of Silver Based Antimicrobial Films for Coating and Food Packaging Applications. Ph.D. Thesis, University of Valencia, Valencia, Spain, February 2014.

8. Grinstead, D. Antimicrobial food packaging: Breakthroughs and benefits that impact food safety. In Proceedings of the International Association for Food Protection (IAFP) Annual Meeting, St. Louis, MO, USA, 31 July-3 August 2016.

9. Mastromatteo, M.; Conte, A.; Del Nobile, M.A. Advances in controlled release devices for food packaging applications. Trends Food. Sci. Technol. 2010, 21, 591-598. [CrossRef]

10. Quintavalla, S.; Vicini, L. Antimicrobial food packaging in meat industry. Meat Sci. 2002, 62, 373-380. [CrossRef]

11. Yildirim, S.; Röcker, B.; Pettersen, M.K.; Nilsen-Nygaard, J.; Ayhan, Z.; Rutkaite, R.; Radusin, T.; Suminska, P.; Marcos, B.; Coma, V. Active Packaging Applications for Food. Compr. Rev. Food Sci. Food Saf. 2018, 17, 165-199. [CrossRef]

12. Ouattara, B.; Simard, R.E.; Piette, G.; Bégin, A.; Holley, R.A. Inhibition of surface spoilage bacteria in processed meats by application of antimicrobial films prepared with chitosan. Int. J. Food Microbiol. 2000, 62, 139-148. [CrossRef]

13. Lopez-Rubio, A.; Almenar, E.; Hernandez-Muñoz, P.; Lagarón, J.M.; Catalá, R.; Gavara, R. Overview of active polymer-based packaging technologies for food applications. Food Rev. Int. 2004, 20, 357-387. [CrossRef]

14. Gherardi, R.; Becerril, R.; Nerin, C.; Bosetti, O. Development of a multilayer antimicrobial packaging material for tomato puree using an innovative technology. LWT-Food Sci. Technol. 2016, 72, 361-367. [CrossRef]

15. Majeed, K.; Jawaid, M.; Hassan, A.; Bakar, A.A.; Khalil, H.A.; Salema, A.A.; Inuwa, I. Potential materials for food packaging from nanoclay/natural fibres filled hybrid composites. Mater. Des. 2013, 46, 391-410. [CrossRef] 
16. Yoshida, C.M.; Maciel, V.B.V.; Mendonça, M.E.D.; Franco, T.T. Chitosan biobased and intelligent films: Monitoring pH variations. LWT-Food Sci. Technol. 2014, 55, 83-89. [CrossRef]

17. Pereira, V.A.; de Arruda, I.N.Q.; Stefani, R. Active chitosan/PVA films with anthocyanins from Brassica oleraceae (Red Cabbage) as time-temperature indicators for application in intelligent food packaging. Food Hydrocoll. 2015, 43, 180-188. [CrossRef]

18. Aider, M. Chitosan application for active bio-based films production and potential in the food industry: Review. LWT-Food Sci. Technol. 2010, 43, 837-842. [CrossRef]

19. Irkin, R.; Guldas, M. Chitosan coating of red table grapes and fresh-cut honey melons to inhibit Fusarium oxysporum growth. J. Food Process. Preserv. 2014, 38, 1948-1956. [CrossRef]

20. Rahman, P.M.; Mujeeb, V.A.; Muraleedharan, K. Flexible chitosan-nano ZnO antimicrobial pouches as a new material for extending the shelf life of raw meat. Int. J. Biol. Macromol. 2017, 97, 382-391. [CrossRef] [PubMed]

21. Ojagh, S.M.; Rezaei, M.; Razavi, S.H. Improvement of the storage quality of frozen rainbow trout by chitosan coating incorporated with cinnamon oil. J. Aquat. Food Prod. Technol. 2014, 23, 146-154. [CrossRef]

22. Yu, T.; Li, H.Y.; Zheng, X.D. Synergistic effect of chitosan and Cryptococcus laurentii on inhibition of Penicillium expansum infections. Int. J. Food Microbiol. 2007, 114, 261-266. [CrossRef] [PubMed]

23. Romanazzi, G.; Feliziani, E.; Baños, S.B.; Sivakumar, D. Shelf life extension of fresh fruit and vegetables by chitosan treatment. Crit. Rev. Food Sci. Nutr. 2017, 57, 579-601. [CrossRef] [PubMed]

24. Fernandez-Saiz, P.; Ocio, M.J.; Lagaron, J.M. Antibacterial chitosan-based blends with ethylene-vinyl alcohol copolymer. Carbohydr. Polym. 2010, 80, 874-884. [CrossRef]

25. Siripatrawan, U.; Vitchayakitti, W. Improving functional properties of chitosan films to be used as active food packaging by incorporation with propolis. Food Hydrocoll. 2016, 61, 695-702. [CrossRef]

26. Schreiber, S.B.; Bozell, J.J.; Hayes, D.G.; Zivanovic, S. Introduction of primary antioxidant activity to chitosan for application as a multifunctional food packaging material. Food Hydrocoll. 2013, 33, 207-214. [CrossRef]

27. Tan, Y.M.; Lim, S.H.; Tay, B.Y.; Lee, M.W.; Thian, E.S. Functional chitosan-based grapefruit seed extract composite films for applications in food packaging technology. Mater. Res. Bull. 2015, 69, 142-146. [CrossRef]

28. Bhoir, S.A.; Chawla, S.P. Silver nanoparticles synthesized using mint extract and their application in chitosan/gelatin composite packaging film. Int. J. Nanosci. 2016, 1650022. [CrossRef]

29. Premanathan, M.; Karthikeyan, K.; Jeyasubramanian, K.; Manivannan, G. Selective toxicity of ZnO nanoparticles toward Gram-positive bacteria and cancer cells by apoptosis through lipid peroxidation. Nanomedicine 2011, 7, 184-192. [CrossRef] [PubMed]

30. De Azeredo, H.M. Antimicrobial nanostructures in food packaging. Trends Food Sci. Technol. 2013, 30, 56-69. [CrossRef]

31. Stoimenov, P.K.; Klinger, R.L.; Marchin, G.L.; Klabunde, K.J. Metal oxide nanoparticles as bactericidal agents. Langmuir 2002, 18, 6679-6686. [CrossRef]

32. Espitia, P.J.P.; Soares, N.D.F.F.; dos Reis Coimbra, J.S.; de Andrade, N.J.; Cruz, R.S.; Medeiros, E.A.A. Zinc oxide nanoparticles: Synthesis, antimicrobial activity and food packaging applications. Food Bioprocess Technol. 2012, 5, 1447-1464. [CrossRef]

33. Chaudhry, Q.; Scotter, M.; Blackburn, J.; Ross, B.; Boxall, A.; Castle, L.; Aitken, R.; Watkins, R. Applications and implications of nanotechnologies for the food sector. Food Addit. Contam. Part A 2008, 25, 241-258. [CrossRef] [PubMed]

34. Bradley, E.L.; Castle, L.; Chaudhry, Q. Applications of nanomaterials in food packaging with a consideration of opportunities for developing countries. Trends Food Sci. Technol. 2011, 22, 604-610. [CrossRef]

35. Al-Naamani, L.; Dobretsov, S.; Dutta, J. Chitosan-zinc oxide nanoparticle composite coating for active food packaging applications. Innov. Food Sci. Emerg. Technol. 2016, 38, 231-237. [CrossRef]

36. Harrigan, W.F. Laboratory Methods in Food Microbiology, 3rd ed.; Gulf Professional Publishing: Houston, TX, USA, 1998.

37. Shapiro, S.S.; Wilk, M.B. An analysis of variance test for normality (complete samples). Biometrika 1965, 52, 591-611. [CrossRef]

38. Pérez-Gago, M.B.; Rhim, J.W. Edible coating and film materials. In Innovations in Food Packaging, 2nd ed.; Academic Press: San Diego, CA, USA, 2014; pp. 325-350.

39. Haldorai, Y.; Shim, J.-J. Chitosan-Zinc Oxide hybrid composite for enhanced dye degradation and antibacterial activity. Compos. Interfaces 2013, 20, 365-377. [CrossRef] 
40. Al-Naamani, L.; Dobretsov, S.; Dutta, J.; Burgess, J.G. Chitosan-ZnO nanocomposite coatings for the prevention of marine biofouling. Chemosphere 2017, 168, 408-417. [CrossRef] [PubMed]

41. Plum, L.M.; Rink, L.; Haase, H. The essential toxin: Impact of zinc on human health. Int. J. Environ. Res. Public Health 2010, 7, 1342-1365. [CrossRef] [PubMed]

42. Opinion of the Scientific Committee on Food (SCF) on the Tolerable Upper Intake Level of Zinc; European Commission: Brussels, Belgium, 2003. Available online: https://ec.europa.eu/food/sites/food/files/ safety/docs/sci-com_scf_out177_en.pdf (accessed on 27 June 2018).

43. Li, Y.C.; Sun, X.J.; Yang, B.I.; Ge, Y.H.; Yi, W.A.N.G. Antifungal activity of chitosan on Fusarium sulphureum in relation to dry rot of potato tuber. Agric. Sci. China 2009, 8, 597-604. [CrossRef]

44. Inatsu, Y.; Kitagawa, T.; Bari, M.L.; Nei, D.; Juneja, V.; Kawamoto, S. Effectiveness of acidified sodium chlorite and other sanitizers to control Escherichia coli O157: H7 on tomato surfaces. Foodborne Pathog. Dis. 2010, 7, 629-635. [CrossRef] [PubMed]

45. Chen, W.; Jin, T.Z.; Gurtler, J.B.; Geveke, D.J.; Fan, X. Inactivation of Salmonella on whole cantaloupe by application of an antimicrobial coating containing chitosan and allyl isothiocyanate. Int. J. Food Microbiol. 2012, 155, 165-170. [CrossRef] [PubMed]

46. Romanazzi, G.; Nigro, F.; Ippolito, A.; Divenere, D.; Salerno, M. Effects of pre-and postharvest chitosan treatments to control storage grey mould of table grapes. J. Food Sci. 2002, 67, 1862-1867. [CrossRef]

47. Badawy, M.E.; Rabea, E.I. Potential of the biopolymer chitosan with different molecular weights to control postharvest gray mould of tomato fruit. Postharvest Biol. Technol. 2009, 51, 110-117. [CrossRef]

48. Liu, J.; Tian, S.; Meng, X.; Xu, Y. Effects of chitosan on control of postharvest diseases and physiological responses of tomato fruit. Postharvest Biol. Technol. 2007, 44, 300-306. [CrossRef]

49. Reddy, M.B.; Angers, P.; Castaigne, F.; Arul, J. Chitosan effects on blackmold rot and pathogenic factors produced by Alternaria alternata in postharvest tomatoes. J. Am. Soc. Hortic. Sci. 2000, 125, 742-747.

50. Li, W.L.; Li, X.H.; Zhang, P.P.; Xing, Y.G. Development of nano-ZnO coated food packaging film and its inhibitory effect on Escherichia coli in vitro and in actual tests. Adv. Mater. Res. 2011, 152, 489-492. [CrossRef]

51. Emamifar, A.; Kadivar, M.; Shahedi, M.; Soleimanian-Zad, S. Evaluation of nanocomposite packaging containing Ag and $\mathrm{ZnO}$ on shelf life of fresh orange juice. Innov. Food Sci. Emerg. Technol. 2010, 11, 742-748. [CrossRef]

52. Malini, M.; Thirumavalavan, M.; Yang, W.Y.; Lee, J.F.; Annadurai, G. A versatile chitosan $/ \mathrm{ZnO}$ nanocomposite with enhanced antimicrobial properties. Int. J. Biol. Macromol. 2015, 80, 121-129. [CrossRef] [PubMed]

53. Liu, Y.; Kim, H.I. Characterization and antibacterial properties of genipin-crosslinked chitosan/poly(ethylene glycol)/ZnO/Ag nanocomposites. Carbohydr. Polym. 2012, 89, 111-116. [CrossRef] [PubMed]

54. Alisashi, A.; Aïder, M. Applications of chitosan in the seafood industry and aquaculture: A review. Food Bioprocess Technol. 2012, 5, 817-830. [CrossRef]

55. Yu, T.; Yu, C.; Chen, F.; Sheng, K.; Zhou, T.; Zunun, M.; Abudu, O.; Yang, S.; Zheng, X. Integrated control of blue mould in pear fruit by combined application of chitosan, a biocontrol yeast and calcium chloride. Postharvest Biol. Technol. 2012, 69, 49-53. [CrossRef]

56. Shi, L.E.; Li, Z.H.; Zheng, W.; Zhao, Y.F.; Jin, Y.F.; Tang, Z.X. Synthesis, antibacterial activity, antibacterial mechanism and food applications of $\mathrm{ZnO}$ nanoparticles: A review. Food Addit. Contam. Part A 2014, 31, 173-186. [CrossRef] [PubMed]

57. Noshirvani, N.; Ghanbarzadeh, B.; Mokarram, R.R.; Hashemi, M.; Coma, V. Preparation and characterization of active emulsified films based on chitosan-carboxymethyl cellulose containing zinc oxide nano particles. Int. J. Biol. Macromol. 2017, 99, 530-538. [CrossRef] [PubMed]

58. Sathe, P.; Laxman, K.; Myint, M.T.Z.; Dobretsov, S.; Richter, J.; Dutta, J. Bioinspired nanocoatings for biofouling prevention by photocatalytic redox reactions. Sci. Rep. 2017, 7, 3624. [CrossRef] [PubMed]

59. Zhang, Z.-Y.; Xiong, H.-M. Photoluminescent ZnO nanoparticles and theirbiological applications. Materials 2015, 8, 3101-3127. [CrossRef]

60. Hernandez-Munoz, P.; Almenar, E.; Del Valle, V.; Velez, D.; Gavara, R. Effect of chitosan coating combined with postharvest calcium treatment on strawberry (Fragaria ananassa) quality during refrigerated storage. Food Chem. 2008, 110, 428-435. [CrossRef] [PubMed]

61. Kader, A.A. Flavor quality of fruits and vegetables. J. Sci. Food Agric. 2008, 88, 1863-1868. [CrossRef] 
62. Beckles, D.M. Factors affecting the postharvest soluble solids and sugar content of tomato (Solanum lycopersicum L.) fruit. Postharvest Biol. Technol. 2012, 63, 129-140. [CrossRef]

63. Lin, L.; Wang, B.; Wang, M.; Cao, J.; Zhang, J.; Wu, Y.; Jiang, W. Effects of a chitosan-based coating with ascorbic acid on post-harvest quality and core browning of 'Yali'pears (Pyrus bertschneideri Rehd.). J. Sci. Food Agric. 2008, 88, 877-884. [CrossRef]

64. Kittur, F.S.; Saroja, N.; Tharanathan, R. Polysaccharide-based composite coating formulations for shelf-life extension of fresh banana and mango. Eur. Food Res. Technol. 2001, 213, 306-311. [CrossRef]

65. Ali, A.; Muhammad, M.T.M.; Sijam, K.; Siddiqui, Y. Effect of chitosan coatings on the physicochemical characteristics of Eksotika II papaya (Carica papaya L.) fruit during cold storage. Food Chem. 2011, 124, 620-626. [CrossRef]

66. Das, D.K.; Dutta, H.; Mahanta, C.L. Development of a rice starch-based coating with antioxidant and microbe-barrier properties and study of its effect on tomatoes stored at room temperature. LWT-Food Sci. Technol. 2013, 50, 272-278. [CrossRef]

67. Lee, L.; Arul, J.; Lenck, R.; Castaigne, F. A review on modified atmosphere packaging and preservation of fresh fruits and vegetables. Physiological basis and practical aspects. Part, I. Packag. Technol. Sci. 1995, 9, 1-17. [CrossRef]

68. Zagory, D. Principle and practice of modified atmosphere packaging of horticultural commodities. In Principles of Modified Atmosphere and Sous Vide Product Packaging; Farber, J.M., Dodda, K.L., Eds.; Economic Publishing Co. Inc.: Lancaster, PA, USA, 1995; pp. 175-204.

69. Munteanu, B.S.; Paslaru, E.; Zemljic, L.F.; Sdrobis, A.; Pricope, G.M.; Vasile, C. Chitosan coating applied to polyethylene surface to obtain food packaging materials. Cellul. Chem. Technol. 2014, 48, 565-575.

70. Rai, D.R.; Balasubramanian, S. Qualitative and textural changes in fresh okra pods (Hibiscus esculentus L.) under modified atmosphere packaging in perforated film packages. Food Sci. Technol. Int. 2009, 15, 131-138. [CrossRef]

71. El Ghaouth, A.; Arul, J.; Ponnampalam, R.; Boulet, M. Use of chitosan coating to reduce water loss and maintain quality of cucumber and bell pepper fruits. J. Food Process. Preserv. 1991, 15, 359-368. [CrossRef]

72. Meng, X.; Li, B.; Liu, J.; Tian, S. Physiological responses and quality attributes of table grape fruit to chitosan preharvest spray and postharvest coating during storage. Food Chem. 2008, 106, 501-508. [CrossRef]

73. Zhou, R.; Mo, Y.; Li, Y.; Zhao, Y.; Zhang, G.; Hu, Y. Quality and internal characteristics of Huanghua pears (Pyrus pyrifolia Nakai, cv. Huanghua) treated with different kinds of coatings during storage. Postharvest Biol. Technol. 2008, 49, 171-179. [CrossRef]

74. Shao, X.F.; Tu, K.; Tu, S.; Tu, J. A combination of heat treatment and chitosan coating delays ripening and reduces decay in "Gala" apple fruit. J. Food Qual. 2012, 35, 83-92. [CrossRef]

75. Olivas, G.I.; Barbosa-Cánovas, G.V. Edible coatings for fresh-cut fruits. Crit. Rev. Food Sci. Nutr. 2005, 45, 657-670. [CrossRef] [PubMed]

76. Vargas, M.; Pastor, C.; Chiralt, A.; McClements, D.J.; Gonzalez-Martinez, C. Recent advances in edible coatings for fresh and minimally processed fruits. Crit. Rev. Food Sci. Nutr. 2008, 48, 496-511. [CrossRef] [PubMed]

77. Dhall, R.K.; Sharma, S.R.; Mahajan, B.V.C. Development of post-harvest protocol of okra for export marketing. J. Food Sci. Technol. 2014, 51, 1622-1625. [CrossRef] [PubMed]

(C) 2018 by the authors. Licensee MDPI, Basel, Switzerland. This article is an open access article distributed under the terms and conditions of the Creative Commons Attribution (CC BY) license (http://creativecommons.org/licenses/by/4.0/). 